\title{
NAFTA and Industrial Pollution: Some General Equilibrium Results
}

\author{
Kenneth A. Reinert* \\ George Mason University \\ David W. Roland-Holst \\ Mills College
}

\begin{abstract}
In recent years, a surge of interest in the linkages between trade and the environment has occurred in the contexts of both regional and multilateral trade agreements. In this paper, we utilize a three-country, applied equilibrium (AGE) model of the North American economy and data from the World Banks Industrial Pollution Projection System (IPPS) to simulate the industrial pollution impacts of trade liberalization under NAFTA. We find that the most serious environmental consequences of NAFTA occur in the base metals sector. In terms of magnitude, the greatest impacts are in the United States and Canada. The Mexican petroleum sector is also a significant source of industrial pollution, particularly in the case of air pollution. For specific pollutants in specific countries, the transportation equipment sector is also an important source of industrial pollution. This is the case for both volatile organic compounds and toxins released into the air in Canada and the United States. Finally, the chemical sector is a significant source of industrial toxin pollution in the United States and Mexico, but not in Canada.
\end{abstract}

- JEL Classifications: F15, Q2, C6

- Key Words: NAFTA, Pollution, Applied General Equilibrium

\footnotetext{
*Corresponding Address: Kenneth A. Reinert, School of Public Policy, George Mason University, 3401 North Fairfax Drive, MS 3B1, Arlington, VA 22201, USA, Tel: +1-703-993-8212, Fax.: + 1-702-993-8215, Email: kreinert@gmu.edu.

C2001-Center for International Economics, Sejong Institution, All Rights Reserved.
} 


\section{Introduction}

In recent years, a surge of interest in the linkages between trade and the environment has occurred in the contexts of both regional trade agreements such the North American Free Trade Area (NAFTA) and multilateral trade agreements such as the Uruguay Round. On the whole, however, the debate over trade and the environment has been more rhetorical than empirical. This is unfortunate because, as has been amply demonstrated (e.g. Runge, 1994, Beghin and Potier, 1997, and Beghin, Roland-Holst, and van der Mensbrugghe, 1997), a priori reasoning alone cannot predict whether trade liberalization will have an overall positive or negative impact on the environment. This fact has prompted Beghin, RolandHolst, and van der Mensbrugghe (1997) to call for "detailed sectoral modeling and estimation" of the linkages between trade and the environment in specific policy contexts.

A few empirical studies do exist. The case of trade and transboundary pollution has been examined by Whalley (1991) and Perronni and Wigle (1994). Economywide models of domestic pollution have been developed by Beghin, Roland-Holst, and van der Mensbrugghe (1995) for the case of Mexico, by Lee and Roland-Holst $(1997 a, b)$ in the case of Indonesia and Japan, and by Ferrantino and Linkins (1999) for the case of the Uruguay Round. Examination of these studies provides further testimony to the usefulness of detailed, empirical analysis.

This paper focuses on the industrial pollution impacts of NAFTA. We utilize a three-country, applied equilibrium (AGE) model of the North American economy and make use of the World Banks Industrial Pollution Projection System (IPPS) to generate results for a detailed set of industrial sectors and pollutants. We simulate the liberalization of tariffs and non-tariff barriers (NTBs) that accompanies NAFTA and provide results for the changes in emissions by industrial sector and pollutant. The results allow us to identify where some of the major environmental impacts of NAFTA are to be found.

We begin in Section II by briefly reviewing the sparse empirical literature on NAFTA and the environment. We then describe in Section III the structure of the AGE model we use to simulate the industrial pollutant effects of NAFTA. We present our simulation results in Section IV and our conclusions in Section V. An appendix describes the construction of the social accounting matrix that comprises the benchmark equilibrium data set of the model. 


\section{NAFTA and the Environment}

As is the case with the general subject of trade and the environment, the literature on NAFTA and the environment is lacking in empirical results. One very notable exception to this is the study by Grossman and Krueger (1993). These authors combined the output effects of NAFTA as simulated by Brown, Deardorff and Stern (1992) with data from the U.S. Environmental Protection Agency on toxic pollution. With regard to the direct impacts of trade liberalization (as opposed to liberalization-induces increases in investment), these authors found that the greatest increases in toxic pollution occur in the U.S. chemicals sector and the Canadian base metals and rubber and plastics products sectors. Other significant trade-induced increases in toxic pollution occurred in the Mexican electrical equipment sector, the U.S. paper products sector, and the Canadian transportation equipment sector.

A second notable exception is the study by Beghin, Roland-Holst, and van der Mensbrugghe (1995). These authors employ a single-country, dynamic AGE model of Mexico. In one simulation scenario, the authors consider "a piecemeal unilateral trade liberalization, along with a modest increase in export prices to mimic terms-of-trade effects that would follow from NAFTA, and increased access to North American markets" (p. 781). The results suggest that trade liberalization contributes to increases in pollution levels, especially in the energy sector. Beghin, Roland-Holst, and van der Mensbrugghe show, however, that these negative pollution impacts can be offset by appropriate abatement policies.

A final empirical study by Abler and Pick (1993) focuses narrowly on the Mexican horticultural sector. Using econometric techniques, these authors conclude that NAFTA contributes to a slight increase in pollution in the Mexican horticultural sector but a slight decrease in pollution in the U.S. horticultural sector. Whether these results can be generalized to the agricultural sector as a whole is not clear.

The present study complements the above studies in providing empirical results for a detailed set of pollutants for all three North American economies. The following section details our modeling approach.

\section{AGE Model Structure}

The AGE model used to simulate the industrial pollution effects of North 
American trade liberalization is a three-country, 26-sector model. ${ }^{1}$ The trade specification follows that of de Melo and Robinson (1989). In each sector of each country, domestic demand is constituted of goods which are differentiated by origin (domestic good, imports from each North American trading partner, and imports from the rest of the world). These goods are aggregated using a nonnested, CES functional form into a single consumption good for both intermediate and final use. Also in each sector of each country, domestic production is allocated using a non-nested CET functional form among differentiated destinations (domestic good, exports to each North American trading partner, and exports to the rest of the world). ${ }^{2}$ With regard to each countrys relationship to the rest of the world, we maintain the small-country assumption. Exchange rates are flexible, while trade balances are fixed.

Production in each sector of each country utilizes physical capital and labor. These factors are assumed to be perfectly mobile among the sectors of each country but immobile among countries. Production takes place under constant returns to scale using CES functional forms for value added and Leontief intermediates. Final demand in each country is modeled using the LES functional form. All markets are perfectly competitive.

The trade-liberalizing experiments we conduct use observed tariff rates for our base year 1991. In addition, we consider very rough estimates of non-tariff barriers using UNCTAD data on trade control measures. As is general practice (e.g. Gaston and Trefler, 1994), we use NTB coverage ratios as ad valorem equivalents. For this reason, our simulations must be interpreted as merely suggestive of the impacts of NAFTA on trade, production, and pollution.

The three-country model is calibrated to a 1991 North American social accounting matrix (SAM). The construction of this matrix and its data sources are documented in the appendix. The IPPS effluent data are utilized at the 2- and 3digit ISIC levels to create satellite environmental accounts to this SAM as suggested by Barker (1992), United Nations (1993a,b), and de Haan and Keuning (1996). As is recommended by their compilers, IPPS effluent data are utilized in

\footnotetext{
${ }^{1}$ Most AGE modelers have included only one or two of the North American countries in their model. An exception to this is Brown, Deardorff and Stern (1992).

${ }^{2}$ In contrast to the approach taken here, Brown et al. (1992) use a firm-level product differentiation approach. One advantage of the country-level product differentiation approach is that it allows for econometric estimation of trade substitution elasticities. Indeed, we make use of the estimates of Shiells and Reinert (1993) in our calibration of the CES import aggregation functions. That said, we have no quarrel with the firm-level differentiation specification. Both approaches have strengths and weaknesses.
} 
Table 1. The IPPS Pollutants

\begin{tabular}{|c|c|c|}
\hline Name & Symbol & Description \\
\hline Particulates & PT & $\begin{array}{l}\text { Fine airborne particles that can damage } \\
\text { respiratory systems. }\end{array}$ \\
\hline Carbon Monoxide & $\mathrm{CO}$ & $\begin{array}{l}\text { A poisonous gas that inhibits the ability of blood to } \\
\text { carry oxygen. }\end{array}$ \\
\hline Sulfur Dioxide & $\mathrm{SO} 2$ & $\begin{array}{l}\text { A gas that can contribute to respiratory disease and } \\
\text { acid rain. }\end{array}$ \\
\hline Nitrogen Dioxide & NO2 & $\begin{array}{l}\text { A gas that contributes to both respiratory disease } \\
\text { and to the formation of acid rain and ozone. }\end{array}$ \\
\hline $\begin{array}{l}\text { Volatile Organic } \\
\text { Compounds }\end{array}$ & VOC & $\begin{array}{l}\text { A class of chemicals associated with skin } \\
\text { reactions, nervous system effects, sick-building } \\
\text { syndrome, and multiple chemical sensitivity. Many } \\
\text { are also suspected carcinogens. }\end{array}$ \\
\hline $\begin{array}{l}\text { Bio-accumulative } \\
\text { Metals }\end{array}$ & $\begin{array}{l}\text { MetAir, MetWat, } \\
\text { MetLand }\end{array}$ & $\begin{array}{l}\text { Metals, including mercury, lead, arsenic, } \\
\text { chromium, nickel, copper, zinc, and cadmium. } \\
\text { They contribute to mental and physical birth } \\
\text { defects. }\end{array}$ \\
\hline Toxic Pollutants & $\begin{array}{l}\text { ToxAir, ToxWat, } \\
\text { ToxLand }\end{array}$ & $\begin{array}{l}\text { A class of chemicals that can damage internal } \\
\text { organs and neurological functions, cause } \\
\text { reproductive problems and birth defects. Many are } \\
\text { also suspected carcinogens. }\end{array}$ \\
\hline $\begin{array}{l}\text { Biological Oxygen } \\
\text { Demand }\end{array}$ & BOD & $\begin{array}{l}\text { Organic water pollutants that remove dissolved } \\
\text { oxygen. They can damage aquatic species and pro- } \\
\text { mote the growth of algae and pathogens. }\end{array}$ \\
\hline $\begin{array}{l}\text { Total Suspended } \\
\text { Solids }\end{array}$ & TSS & $\begin{array}{l}\text { Non-organic, non-toxic particles that can damage } \\
\text { aquatic ecosystems and promote the growth of } \\
\text { pathogens. }\end{array}$ \\
\hline
\end{tabular}

Source: World Bank Industrial Pollution Projection System

their per-employee form. Table 1 describes the IPPS pollutants. ${ }^{3}$ In the case of air pollution, the IPPS data include particulates, carbon monoxide, sulfur dioxide, nitrogen dioxide, and volatile organic compounds. In the case of industrial bioaccumulative metals and toxins, the data distinguish among transmission to air, water, and land. Finally, in the case of water pollution, the data distinguish between biological oxygen demand and total suspended solids. The result is a significant amount of detail in both sectoral and pollutant dimensions which complement the earlier work of Grossman and Krueger (1993).

The calibration of the model also requires a set of behavior parameters. Elastici-

\footnotetext{
${ }^{3}$ On the IPPS, see Hettige, Lucas and Wheeler (1992) and the references therein. See also the web-site listed in our data sources at the end of the paper.
} 
ties of substitution between labor and capital were taken from Reinert and RolandHolst (1995) for the United States and Mexico and from Delorme and Lester (1990) for Canada. The elasticities of substitution among imports and do-mestic goods were taken from Shiells and Reinert (1993) for the United States and Canada and from Sobarzo (1992) for Mexico. Elasticities of transformation among exports and domestic supply were taken from Reinert and Roland-Holst (1995).

\section{Simulation Results}

For the purposes of this paper, we focus a simulation exercise closest to that considered by Brown, Deardorff and Stern (1992) and, therefore, by Grossman and Krueger (1993). We consider the removal of both tariffs as measured by their observed values and NTBs as measured by coverage ratios. We assume that each North American trading partner maintains its existing protection with respect to the rest of the world. Additionally, as is standard practice in most trade policy models, we assume that total labor supply is fixed in each country. The results of these simulations for each industrial sector and IPPS pollutant are presented in

Table 2. Industrial Air Pollution (thousands of pounds)

\begin{tabular}{|lrrrrrrr|}
\hline Sector & Can & Can & Can & Can & Can & US & \multicolumn{1}{c|}{ US } \\
\cline { 2 - 7 } & PT & \multicolumn{1}{c}{ CO } & SO2 & NO2 & VOC & \multicolumn{1}{c}{ PT } & \multicolumn{1}{c}{ CO } \\
\hline petrol & 4,384 & 14,077 & 27,710 & 16,248 & 12,220 & 1,067 & 3,426 \\
foodpr & 325 & 97 & 354 & 355 & 92 & 2,782 & 828 \\
bever & 25 & 20 & 383 & 244 & 414 & -37 & -30 \\
tobac & 2 & 10 & 123 & 74 & 24 & -4 & -19 \\
textl & -55 & -48 & -261 & -343 & -157 & 180 & 158 \\
cloth & 0 & 0 & 3 & 1 & 1 & 0 & 0 \\
leath & 11 & 1 & 20 & 5 & 35 & 140 & 18 \\
paper & $-1,821$ & $-10,609$ & $-9,323$ & $-5,141$ & $-2,044$ & 33 & 192 \\
chem & -293 & $-2,630$ & $-1,552$ & $-1,516$ & $-1,279$ & 1,276 & 11,472 \\
rubber & 99 & 37 & 856 & 294 & 1,123 & 137 & 51 \\
nmtmn & -476 & -119 & -688 & -541 & -64 & -111 & -28 \\
bsmetl & 5,016 & 30,825 & 40,248 & 5,759 & 2,543 & 12,374 & 76,052 \\
wdmetl & 637 & 1,159 & 253 & 493 & 1,325 & 2,920 & 5,314 \\
nelcmc & 1 & 9 & 9 & 4 & 10 & 71 & 518 \\
elcmc & 33 & 168 & 305 & 150 & 204 & -10 & -53 \\
trnseq & 3,266 & 5,561 & 7,908 & 4,109 & 29,531 & 3,531 & 6,013 \\
othmn & 2 & 1 & 3 & 3 & 18 & 1 & 0 \\
Total & 11,156 & 38,558 & 66,352 & 20,199 & 43,997 & 24,349 & 103,913 \\
\hline
\end{tabular}


Table 2. Continued

\begin{tabular}{|lrrrrrrrr|}
\hline \multirow{2}{*}{ Sector } & \multicolumn{1}{c}{ US } & \multicolumn{1}{c}{ US } & \multicolumn{1}{c}{ US } & Mex & Mex & Mex & Mex & \multicolumn{1}{c|}{ Mex } \\
\cline { 2 - 8 } & SO2 & NO2 & VOC & PT & CO & SO2 & NO2 & VOC \\
\hline petrol & 6,743 & 3,954 & 2,974 & 15,322 & 49,196 & 96,840 & 56,783 & 42,705 \\
foodpr & 3,035 & 3,042 & 791 & 341 & 101 & 372 & 372 & 97 \\
bever & -570 & -363 & -616 & 39 & 31 & 598 & 381 & 646 \\
tobac & -239 & -145 & -48 & 0 & 2 & 19 & 12 & 4 \\
textl & 857 & 1,126 & 515 & 351 & 309 & 1,674 & 2,199 & 1,007 \\
cloth & -3 & -1 & -1 & 0 & 0 & 1 & 0 & 0 \\
leath & 254 & 64 & 442 & 8 & 1 & 14 & 3 & 24 \\
paper & 169 & 93 & 37 & -197 & $-1,149$ & $-1,009$ & -557 & -221 \\
chem & 6,770 & 6,614 & 5,581 & 845 & 7,598 & 4,484 & 4,381 & 3,696 \\
rubber & 1,188 & 408 & 1,559 & 11 & 4 & 94 & 32 & 124 \\
nmtmn & -160 & -126 & -15 & 1,892 & 475 & 2,735 & 2,150 & 253 \\
bsmetl & 99,301 & 14,209 & 6,275 & 1,344 & 8,261 & 10,786 & 1,543 & 682 \\
wdmetl & 1,162 & 2,261 & 6,077 & 763 & 1,388 & 304 & 591 & 1,588 \\
nelcmc & 479 & 215 & 545 & 25 & 184 & 170 & 76 & 193 \\
elcmc & -96 & -47 & -64 & 36 & 185 & 337 & 166 & 226 \\
trnseq & 8,550 & 4,443 & 31,930 & 294 & 500 & 711 & 370 & 2,656 \\
othmn & 2 & 1 & 9 & 3 & 1 & 6 & 6 & 37 \\
Total & 127,442 & 35,750 & 55,991 & 21,076 & 67,088 & 118,136 & 68,509 & 53,716 \\
\hline
\end{tabular}

Sectors are: petroleum; food processing; beverages; tobacco; textiles; clothing; leather; paper; chemicals; rubber; non-metalic mineral products; base metals; wood and metal products; non-electrical machinery; electrical machinery; transportation equipment; and other manufactures.

Pollutants are: PT- particulates; $\mathrm{CO}$ - carbon monoxide; SO2- sulfur dioxide; NO2- nitrogen dioxide; VOC- volatile organic compounds.

Tables 2 through $5 .{ }^{4}$

Table 2 presents the changes in industrial air pollution caused by trade liberalization in North America for each industrial sector of the model. The evidence presented in this table suggests that the industrial air pollution generated as a result of NAFTA will be concentrated in a few particular sectors. These are petroleum, base metals, and transportation equipment. For particulates, carbon monoxide, sulfur dioxide, and nitrogen dioxide, the greatest increases occur in the U.S. base metals sector and in the Mexican petroleum sector. ${ }^{5}$ In the case of

\footnotetext{
${ }^{4}$ Missing from our analysis is the impact of NAFTA on pollution emissions from the Canadian, U.S., and Mexican agricultural sectors. We refer readers to Abler and Pick (1993) for the case of horticulture in Mexico.

${ }^{5}$ Pollution associated with the petroleum sector in Mexico has been a significant part of the debate over NAFTA and the environment. See Beghin, Roland-Holst, and van der Mensbrugghe (1995) and Commission for Environmental Cooperation (1996).
} 
Table 3. Industrial Bio-accumulative Metals Pollution (thousands of pounds)

\begin{tabular}{|c|c|c|c|c|c|c|c|c|c|}
\hline & Can & Can & Can & US & US & US & Mex & Mex & Mex \\
\hline Sector & $\begin{array}{l}\text { Met- } \\
\text { Air }\end{array}$ & $\begin{array}{l}\text { Met- } \\
\text { Wat }\end{array}$ & $\begin{array}{l}\text { Met- } \\
\text { Land }\end{array}$ & $\begin{array}{l}\text { Met- } \\
\text { Air }\end{array}$ & $\begin{array}{l}\text { Met- } \\
\text { Wat }\end{array}$ & $\begin{array}{l}\text { Met } \\
\text { Land }\end{array}$ & $\begin{array}{c}\text { Met- } \\
\text { Air }\end{array}$ & $\begin{array}{l}\text { Met- } \\
\text { Wat }\end{array}$ & $\begin{array}{l}\text { Met- } \\
\text { Land }\end{array}$ \\
\hline petrol & 8 & 3 & 84 & 2 & 1 & 20 & 30 & 12 & 292 \\
\hline foodpr & 0 & 0 & 1 & 0 & 0 & 5 & 0 & 0 & 1 \\
\hline bever & 0 & 0 & 3 & 0 & 0 & -5 & 0 & 0 & 5 \\
\hline tobac & 0 & 0 & 0 & 0 & 0 & 0 & 0 & 0 & 0 \\
\hline textl & 0 & 0 & -6 & 1 & 0 & 21 & 3 & 0 & 41 \\
\hline cloth & 0 & 0 & 0 & 0 & 0 & 0 & 0 & 0 & 0 \\
\hline leath & 0 & 0 & 12 & 0 & 0 & 151 & 0 & 0 & 8 \\
\hline paper & -2 & -3 & -9 & 0 & 0 & 0 & 0 & 0 & -1 \\
\hline chem & -3 & -3 & -99 & 13 & 12 & 432 & 8 & 8 & 286 \\
\hline rubber & 2 & 0 & 95 & 2 & 1 & 132 & 0 & 0 & 10 \\
\hline nmtmn & -1 & 0 & -8 & 0 & 0 & -2 & 4 & 0 & 31 \\
\hline bsmetl & 261 & 19 & 7,482 & 644 & 47 & 18,459 & 70 & 5 & 2,005 \\
\hline wdmetl & 2 & 0 & 53 & 9 & 2 & 243 & 2 & 0 & 63 \\
\hline nelcmc & 0 & 0 & 2 & 5 & 0 & 94 & 2 & 0 & 33 \\
\hline elcmc & 2 & 0 & 68 & -1 & 0 & -22 & 2 & 0 & 76 \\
\hline trnseq & 93 & 2 & 1,142 & 101 & 2 & 1,234 & 8 & 0 & 103 \\
\hline othmn & 0 & 0 & 3 & 0 & 0 & 1 & 0 & 0 & 6 \\
\hline Total & 362 & 19 & 8,821 & 776 & 65 & 20,765 & 130 & 26 & 2,960 \\
\hline
\end{tabular}

Sectors are: petroleum; food processing; beverages; tobacco; textiles; clothing; leather; paper; chemicals; rubber; non-metalic mineral products; base metals; wood and metal products; non-electrical machinery; electrical machinery; transportation equipment; and other manufactures.

Pollutants are: Metals to air, water, and land.

volatile organic compounds, however, the transportation equipment sectors of Canada and the United States are large sources. In terms of total air pollution emissions, the greatest increases are of carbon monoxide and sulfur dioxide in the United States and sulfur dioxide in Mexico. Significant reductions in air pollution occur in the Canadian and Mexican paper sectors and in the Canadian chemicals sector.

Table 3 addresses industrial bio-accumulative metals pollution. Here, the petroleum sector plays a less important role than base metals and transportation equipment. The largest emissions are to land, and these occur in the Canadian and U.S. base metals and transportation equipment sectors and in the Mexican base metals sector. In terms of total emissions, the United States leads both Canada and Mexico, primarily as a result of changes in its base metals sector. Again the Canadian chemicals sector registers improvement in emissions, although these are 
Table 4. Industrial Toxin Pollution (thousands of pounds)

\begin{tabular}{|lrrrrrrrrr|}
\hline \multirow{2}{*}{ Sector } & Can & Can & Can & US & US & US & Mex & Mex & Mex \\
\cline { 2 - 8 } & Tox- & Tox- & Tox- & Tox- & Tox- & Tox- & Tox- & Tox- & Tox- \\
& \multicolumn{1}{c}{ Wat } & Land & \multicolumn{1}{c}{ Air } & Wat & Land & Air & Wat & Land \\
\hline Petrol & 1,140 & 80 & 4,334 & 277 & 20 & 1,055 & 3,984 & 280 & 15,147 \\
Foodpr & 14 & 4 & 54 & 122 & 34 & 467 & 15 & 4 & 57 \\
Bever & 15 & 2 & 11 & -22 & -3 & -17 & 23 & 3 & 18 \\
Tobac & 26 & 0 & 3 & -51 & 0 & -5 & 4 & 0 & 0 \\
Textl & -106 & -20 & -63 & 349 & 65 & 208 & 682 & 126 & 406 \\
Cloth & 1 & 0 & 1 & -1 & 0 & -1 & 0 & 0 & 0 \\
Leath & 46 & 2 & 89 & 589 & 20 & 1,125 & 32 & 1 & 60 \\
Paper & $-1,906$ & -437 & -726 & 35 & 8 & 13 & -206 & -47 & -79 \\
Chem & -967 & -287 & $-2,230$ & 4,217 & 1,253 & 9,729 & 2,793 & 830 & 6,443 \\
Rubber & 899 & 2 & 331 & 1,247 & 3 & 459 & 99 & 0 & 36 \\
Nmtmn & -28 & -1 & -37 & -6 & 0 & -9 & 110 & 3 & 145 \\
Bsmetl & 2,867 & 305 & 9,479 & 7,072 & 752 & 23,388 & 768 & 82 & 2,540 \\
Wdmetl & 364 & 8 & 189 & 1,669 & 37 & 867 & 436 & 10 & 227 \\
Nelcmc & 6 & 0 & 4 & 348 & 9 & 230 & 124 & 3 & 82 \\
Elcmc & 284 & 3 & 284 & -90 & -1 & -90 & 315 & 3 & 315 \\
Trnseq & 15,861 & 61 & 6,843 & 17,149 & 66 & 7,399 & 1,427 & 5 & 615 \\
Othmn & 31 & 0 & 15 & 15 & 0 & 7 & 62 & 1 & 29 \\
Total & 18,549 & -277 & 18,581 & 32,920 & 2,261 & 44,826 & 10,668 & 1,304 & 26,044 \\
\hline
\end{tabular}

Sectors are: petroleum; food processing; beverages; tobacco; textiles; clothing; leather; paper; chemicals; rubber; non-metalic mineral products; base metals; wood and metal products; non-electrical machinery; electrical machinery; transportation equipment; and other manufactures.

Pollutants are: Toxins to air, water, and land.

slight.

Table 4 presents the changes in industrial toxin pollution. Here, transmission to air is important along with transmission to land. This is especially the case for the transportation equipment sector in Canada. The base metals sector is also important for the transmission of toxins to land in this country. ${ }^{6}$ In the United States and Mexico, the chemical sector appears as significant sources of toxins. Importantly, this is not the case for Canada where this is a reduction of toxin emissions in the chemical sector. ${ }^{7}$ As was the case in Tables 2 and 3, this result demonstrates the importance of the general equilibrium analysis of trade and the environment. If reflects the comparative advantage of the U.S. and Mexican chemical sectors over their Canadian counterpart. The U.S. base metals and

\footnotetext{
${ }^{6}$ Qualitatively, these results for Canada agree with those of Grossman and Krueger (1993).

${ }^{7}$ Grossman and Krueger (1993) show a decrease in toxin pollution from the Mexican chemicals sector in their trade-liberalization alone case, but an increase in the trade and investment liberalization case.
} 
Table 5. Industrial Water Pollution (thousands of pounds)

\begin{tabular}{|lrrrrrr|}
\hline \multirow{2}{*}{ Sector } & Can & Can & US & US & Mex & Mex \\
\cline { 2 - 7 } & BOD & \multicolumn{1}{c}{ TSS } & BOD & TSS & BOD & \multicolumn{1}{c|}{ TSS } \\
\hline Petrol & 271,335 & 66 & 325 & 948 & 4,664 \\
Foodpr & 483 & 120 & 4,136 & 1,032 & 506 & 126 \\
Bever & 164 & 297 & -245 & -441 & 257 & 463 \\
Tobac & 0 & 0 & 0 & 0 & 0 & 0 \\
Textl & 0 & 0 & 0 & 0 & 0 & 0 \\
Cloth & 0 & 0 & 0 & 0 & 0 & 0 \\
Leath & 8 & 17 & 104 & 216 & 6 & 12 \\
Paper & $-5,004$ & $-16,838$ & 91 & 305 & -542 & $-1,823$ \\
Chem & -365 & $-1,224$ & 1,594 & 5,341 & 1,056 & 3,537 \\
Rubber & 170 & 466 & 236 & 647 & 19 & 51 \\
Nmtmn & -1 & -13 & 0 & -3 & 6 & 51 \\
Bsmetl & 2,245 & 152,998 & 5,540 & 377,481 & 602 & 41,003 \\
Wdmetl & 18 & 140 & 81 & 642 & 21 & 168 \\
Nelcmc & 0 & 1 & 2 & 38 & 1 & 13 \\
Elcmc & 12 & 17 & -4 & -5 & 13 & 19 \\
Trnseq & 14 & 102 & 15 & 110 & 1 & 9 \\
Othmn & 0 & 414 & 0 & 204 & 0 & 825 \\
Total & $-1,986$ & 137,832 & 11,615 & 385,891 & 2,893 & 49,120 \\
\hline
\end{tabular}

Sectors are: petroleum; food processing; beverages; tobacco; textiles; clothing; leather; paper; chemicals; rubber; non-metalic mineral products; base metals; wood and metal products; non-electrical machinery; electrical machinery; transportation equipment; and other manufactures.

Pollutants are: BOD- biological oxygen demand; and TSS- total suspended solids.

transportation equipment sectors and the Mexican petroleum sector are also significant sources of toxins, ${ }^{8}$ and in terms of total emissions, the U.S. leads with toxic emissions to land and air.

Finally, Table 5 presents the simulation results for water pollution. The base metals sector is again a crucial source of effluents. This is particularly the case for total suspended solids in all three countries. In the case of biological oxygen demand, there is actually an overall decrease in Canada due to the contraction of the paper products sector. The Mexican petroleum sector is a significant source of total suspended solids, but this is an order of magnitude less than in its base metals sector. By far, the greatest concern with regard to water pollution as a result of NAFTA trade liberalization is the increase in total suspended solids from the base metals sector of the United States.

\footnotetext{
${ }^{8}$ Here, our results are in contradiction to those of Grossman and Krueger (1993). This is most likely due
} to the different way we model NTBs compared to Brown, Deardorff and Stern (1992). 


\section{Conclusions}

The results presented in this paper need to be interpreted with caution. The NTB measures used are in coverage ratio form and thus involve a degree of inaccuracy. Further, the IPPS data are based on conditions in the United States. Although there is evidence that the ranking of pollution intensities is invariant among OECD countries (Hettige, Lucas and Wheeler, 1992), this is obviously not the case with the cardinal values themselves. In our view, the results of Tables 2 through 5 must be considered in ordinal terms as indicating where the most vexing pollution consequences of NAFTA exist. In this sense, the results provide some strong conclusions. ${ }^{9}$

The most serious environmental consequences of NAFTA occur in the base metals sector. In terms of magnitude, the greatest impacts are in the United States and Canada, and this is the case for most of the pollutants considered. As alleged in the debate over NAFTA and the environment, the Mexican petroleum sector is a significant source of industrial pollution, particularly in the case of air pollution. For specific pollutants in specific countries, the transportation equipment sector is also an important source of industrial pollution. This is the case for both volatile organic compounds and toxins released into the air in Canada and the United States. Finally, as suggested by Grossman and Kruegers (1993) results, the chemical sector is a significant source of industrial toxin pollution in the United States and Mexico, but not in Canada. The general equilibrium impact of North American trade liberalization result in a reduction of toxin pollution in the Canadian chemicals sector.

It is hoped that the results of this paper will contribute to the ongoing discussions of the impacts of NAFTA on the environment and to the work of relevant organizations such as the Montreal-based Commission for Environmental Cooperation (CEC). The results suggest that it may be necessary to develop environmental policies that target specific industrial sources of pollution caused by increased economic integration among the three North American economies.

\section{Acknowledgements}

Senior authorship is not assigned. We would like to thank Hugh Arce, Gordon Blaney, Charles Bowman, Antonio Aguilar Bueno, Joseph Flynn, Joseph

\footnotetext{
${ }^{9}$ It is certainly not the case, as suggested by Kaufman, Pauly, and Sweitzer (1993), that one can say very little about the probable impacts of NAFTA on the environment.
} 
Francois, Luis Alberto Ibarra, Mark Planting, Erik Poole, Ronald Rioux, Clint Shiells, David Wheeler, and Colleen Williams for data. This has been supported by the Office of the Great Lakes through the Michigan Great Lakes Protection Fund and the Commission for Environmental Cooperation.

Date accepted: November 2000

\section{References}

Abler, D.G. and D. Pick (1993), "NAFTA, Agriculture and the Environment in Mexico," American Journal of Agricultural Economics 75, pp. 794-798.

Barker, T. (1992), "Accounting for the Environment," Cambridge University EnergyEnvironment-Economy Modeling Discussion Paper.

Beghin, J. and M. Potier (1997), "Effects of Trade Liberalization on the Environment in the Manufacturing Sector," The World Economy 20, pp. 435-456.

Beghin, J., D.W. Roland-Holst and D. van der Mensbrugghe (1995), “Trade Liberalization and the Environment in the Pacific Basin: Coordinated Approaches to Mexican Trade and Environmental Policy," American Journal of Agricultural Economics 77, pp. 778-785.

Beghin, J., D.W. Roland-Holst and D. van der Mensbrugghe (1997), “Trade and Pollution Linkages: Piecemeal Reform and Optimal Intervention," Canadian Journal of Economics 30, pp. 442-455.

Brown, D.K., A.V. Deardorff and R.M. Stern (1992), "A North American Free Trade Agreement: Analytical Issues and a Computational Assessment," The World Economy 15, pp. 11-30.

Commission for Environmental Cooperation (1996), NAFTA Effects: Claims and Arguments 1991-1994, Montréal.

Delorme, F. and J. Lester (1990), "The Structure of Production in Ten Canadian Industries," Empirical Economics 15, pp. 315-346.

Ferrantino, M.J. and L.A. Linkins (1999), "The Effects of Global Trade Liberalization on Toxic Emissions in Industry," Weltwirtschaftliches Archiv 135, pp. 128-155.

Gaston, N. and D. Trefler (1994), "Protection, Trade and Wages: Evidence from US Manufacturing," Industrial and Labor Relations Review 47, pp. 574-593.

Grossman, G.M. and A.B. Krueger (1993), "Environmental Impacts of a North American Free Trade Agreement," in P. Garber (ed.), The Mexico-U.S. Free Trade Agreement, Cambridge, MIT Press.

de Haan, M. and S.J. Keuning (1996), "Taking the Environment into Accounting: The NAMEA Approach," Review of Income and Wealth 42, pp. 131-148.

Hettige, H., R.E.B. Lucas and D. Wheeler (1992), "The Toxic Intensity of Industrial Production: Global Patterns, Trends and Trade Policy," American Economic Review, 
82, pp. 478-481.

Kaufmann, R.K., P. Pauly and J. Sweitzer (1993), "The Effects of NAFTA on the Environment," Energy Journal 14, pp. 217-240.

Lee, H. and D.W. Roland-Holst (1997a), "The Environment and Welfare Implications of Trade and Tax Policy," Journal of Development Economics 52, pp. 65-82.

Lee, H. and D.W. Roland-Holst (1997b), "Trade and the Environment," in J.F. Francois and K.A. Reinert (eds.), Applied Methods for Trade Policy Analysis, Cambridge, Cambridge University Press.

de Melo, J. and S. Robinson (1989), "Product Differentiatioin and the Treatment of Foreign Trade in Computable General Equilibrium Models of Small Economies," Journal of International Economics 27, 47-67.

Perroni, C. and R.M. Wigle (1994), "International Trade and Environmental Quality:

How Important are the Linkages?" Canadian Journal of Economics 27, pp. 551567.

Reinert, K.A. and D.W. Roland-Holst (1995) "Parameter Estimates for US Trade Policy," Working Paper 95-01, Kalamazoo College.

Runge, C.F. (1994), Freer Trade, Protected Environment, New York, Council on Foreign Relations Press.

Schneider, M.H. and S.A. Zenios (1990), “A Comparative Study of Algorithms for Matrix Balancing,” Operations Research 38, pp. 439-455.

Shiells, C.R. and K.A. Reinert (1993), "Armington Models and Terms-of-Trade Effects:

Some Econometric Evidence for North America," Canadian Journal of Economics 26, pp. 299-316.

Sobarzo, H.E. (1992), "A General Equilibrium Analysis of the Gains from Trade for the

Mexican Economy," The World Economy 15, pp. 83-100.

United Nations (1993a), System of National Accounts 1993, New York.

United Nations (1993b), Integrated Environmental and Economic Accounting, Series F, No. 61, New York.

Whalley, J. (1991), "The Interface between Environmental and Trade Policies," The Economic Journal 101, pp. 180-189.

\section{Data Sources}

Banco de México (1993), The Mexican Economy 1993, Mexico City.

General Agreement on Tariffs and Trade (1993), Trade Policy Review: Mexico 1993, Geneva.

Instituto Nacional de Estadística, Geographía e Informática (1992), Sistema de Cuentas Nacionales de Mexico: Cálculo Preliminar, Mexico City.

International Monetary Fund (1992), Direction of Trade Statistics Yearbook 1992, Washington, DC.

International Monetary Fund (1993), International Financial Statistics, Washington, DC. 
Organization for Economic Co-operation and Development (1992), OECD Economic Surveys: Mexico, Paris.

Statistics Canada (1993a), National Income and Expenditure Accounts, Ottawa. Statistics Canada (1993b), Canadas Balance of International Payments, Ottawa. U.S. Department of Commerce (1992a), Survey of Current Business 72, June. U.S. Department of Commerce (1992b), Survey of Current Business 72, July. World Bank, Industrial Pollution Projection System, www.worldbank.org/nipr/ index.htm.

\section{Appendix: SAM Construction}

This appendix provides a brief description of the construction of the 1991 social accounting matrix (SAM) of North America. Construction of the 1991 North American SAM began with the transformation of 1991 national accounts for each country into three separate macroeconomic SAMs. For this purpose, Canadian macroeconomic data were taken from Statistics Canada (1993a and 1993b), U.S. macroeconomic data were taken from U.S. Department of Commerce (1992b) and Mexican macroeconomic data were taken from OECD (1992), Banco de México (1993), Instituto National de Estadística, Geographía e Informática (1992) and International Monetary Fund (1993). Next, individual macroeconomic SAMs were joined together into a North American macroeconomic SAM using market exchange rates from International Monetary Fund (1993) and aggregate trade flows taken from International Monetary Fund (1992). Adjustments for maquiladora trade were made with data from Banco de México (1993) and factor service and capital flows were added using data from U.S. Department of Commerce (1992a) and Statistics Canada (1993b).

The next stage of SAM construction involved estimation of the 26 sectoral accounts of each country. Labor value added, property value added, indirect business taxes, value added taxes (for Mexico), domestic final demand, imports, exports, and inter-industry transactions were disaggregated for each country into the 26 sectors. For labor value added, property value added, indirect business taxes, value added taxes, and domestic final demand, this was done using shares from input-output accounts. For Canada, we used 1990 Statistics Canada input output accounts. For the United States, we used 1987 U.S. Department of Labor

\footnotetext{
${ }^{10}$ These are census based. At the time of the work on the SAM, the 1987 U.S. Department of Commerce input-output accounts were not available.

${ }^{11} \mathrm{SECOFI}$ is the acronym for Secretaría de Comercio y Fomento Industrial.
} 
input-output accounts. ${ }^{10}$ In the case of Mexico, we used 1989 SECOFI input output accounts. ${ }^{11}$ For imports and exports, the disaggregation was conducted using 10-digit HTS data for the United States and 3-digit SITC data for all three countries. The former were obtained from U.S. Department of Commerce data tapes, and the latter were obtained from United Nations data tapes. Canadian tariffs were estimated from the 1990 input-output data, U.S. tariffs were estimated from the Department of Commerce data, and Mexican tariffs were estimated from data presented in General Agreement on Tariffs and Trade (1993).

For Canada and the United States, 1991 interindustry transactions were estimated using make and use tables for 1990 and 1987, respectively. Make and use tables were balanced using 1991 gross activity output and the RAS procedure. ${ }^{12}$ We then removed activity accounts using the Pyatt (1985) procedure. For Mexico, the 1989 transactions matrix was updated to 1991 using 1991 value added, final demand, import and export data.

${ }^{12}$ On the RAS procedure, see Schneider and Zenios (1990). 